\title{
The scope of reciprocal degree operators and degree pluralities*
}

\author{
I-Ta Chris Hsieh \\ National Tsing Hua University, Taiwan
}

\begin{abstract}
A degree sentence such as John and Mary are equally tall conveys both reciprocity and equivalence and hence are termed 'reciprocal equatives'. This paper investigates this degree construction; building on Schwarz's (2007) pioneer study, I suggest an account for this degree construction that covers a wider range of data. To the extent that the proposal is on the right track, it provides new support for building in plurality in the domain of degrees, an idea that has been put forward by Beck (2010, 2014) and Dotlačil \& Nouwen (2016).
\end{abstract}

Keywords: reciprocal equative, degree plurality, vagueness, plural predication

\section{Introduction}

This paper aims to provide a proper analysis for the degree construction some examples of which are given in (1-3).

(1) English

John and Mary are equally heavy.

(2) German

Hans und Maria sind gleich schwer.

Hans and Maria are equally heavy

(3) Mandarin

Yuēhàn hé Mălì yíyàng zhòng.

John and Mary equally heavy

This degree construction has been dubbed 'reciprocal equatives' (henceforth, RE) by Schwarz (2007). As noted by him, the meaning of this construction may characterized as 'reciprocal' and 'equivalent': all these examples express that John's weight and Mary's are equivalent to each other, and these meaning components are carried out by the reciprocal equative morpheme equally/gleich/yíyàng.

* This research is supported by the grant 'The interaction between Evidentials and Modality in Natural Language- A case study in Turkish' (MOST 105-2410-H-007-060- ), which is provided by the Ministry of Science and Technology of Taiwan. I thank the participants in SALT 27 for their valuable comments and suggestions. All the errors are mine.

C)2017 Hsieh 
Reciprocal Degree operators and degree pluralities

\subsection{Types of Reciprocal Equatives}

In addition to predicative REs, we may find adnominal ones (see the German examples (4), (6) and their Mandarin counterparts).

(4) Hans hat gleich longe Ohren.

Hans has equally long ears

'Hans has equally long ear.'

(5) Yuehàn yŏu-zhe yíyàng cháng-de ĕrduo.

John have-PROG equally long-MOD ear

'John has equally long ears.'

(6) Hans und Maria tragen gleich schwere Rucksäcke.

Hans and Maria carry equally heavy backpacks

'Hans and Maria carry equally heavy backpacks.'

(7) Yuēhàn hé Mălì bēi-le yíyàng zhòng-de bēibāo.

John and Mary carry-PERF equally heavy-MOD backpack

'John and Mary carry/carried equally heavy backpacks.'

Degree comparison in a RE may be along the dimension of quantity, as shown in the German examples (8), (10) and their Mandarin counterparts (9) and (11).

(8) Hans und Maria haben gleich viele Katzen.

Hans and Maria have equally many cats

'Hans and Maria have equally many cats.'

(9) Yuēhàn hé Mălì yăng-le yíyàng dūo-de māo.

John and Mary keep-PERF equally many-MOD cat

'John and Mary have equally many cats.'

(10) Hans hat gleich viele Hunde und Katzen.

Hans has equally many dogs and cats

'Hans has equally many dogs and cats.'

(11) Yuēhàn yăng-le yíyàng dūo-de gŏu gēn māo.

John keep-PERF equally many-MOD dog and cat

'John has equally many dogs and cats.

As indicated by the ungramaticality in (12), there is a need to distinguish an amount RE (e.g., (8-11) from those like (4-7), despite the fact that in all these cases the RE morpheme modifies a pre-nominal adjective: although the RE morpheme, in both cases, occur in pre-nominal position, a simple plural noun modified by the Q-adjective viele 'many' does not suffice to license it.

(12) *Hans hat gleich viele Haustiere.

Hans has equally many pets 
At least in Mandarin, objects in comparison in the meaning of a RE may be contributed by a universal quantifier, as shown in (13-14).

mĕi-ge xuéshēng dōu păo-de yíyàng kuài. every-CL student ALL run-PART equally fast 'Every student runs/ran equally fast.'

(14) Zhāngsān gěi-le mĕi-ge xuéshēng yī-tiáo yíyàng cháng-de Zhangsan give-PERF every-CLF student one-CLF equally long-MOD shéngzi.

rope

'Zhangsan gave every student an equally long rope.'

Schwarz (2007) also notes that in German a predicative RE with a universal subject like (15) sounds significantly better than one with a singular nominal subject (16). ${ }^{1}$

(15) Jeder Junge war gleich schnell. every boy was equally fast

* Maria ist gleich schwer. Maria is equally heavy

\subsection{Vagueness and context dependency}

Intuitions around an adnominal RE are not always as clear as we hope they are. Consider (6)/(7); these examples may be easily judged true in a scenario like (17), where John and Mary each carry just one backpack.

(17) John carries one backpack weighing 10kgs;

Mary carries one weighing 10kgs.

The situation gets complicated when objects in comparison are in a relatively large group. Consider the scenario in (18), where John and Mary each carry more than

1 The fact that English Maria is equally heavy is grammatical on a reciprocal, discourse anaphoric interpretation is not in the concern of this paper. As Schwarz (2007) notes, such an interpretation, in some dialects of German, is not possible for gleich. To my ear, Mandarin yíyàng carries an interpretation of this kind only if it is accompanied by the additive particle yĕi 'also'.

i. Yuēhàn bēi-le yí-ge wŭshí gōngjīn zhòng-de bèibāo; Mălì */?? (yěi) bēi-le John carry-PERF one-CLF 50 kg heavy-MOD backpack; Mary also carry yí-ge yíyàng zhòng-de bèibāo. one-CLF equally heavy-MOD backpack

Intended: 'John carried a backpack that weighs 50kg; Mary carried an equally heavy backpack.'

$\cong$ John and Mary each carry one 50kg backpack. 
Reciprocal Degree operators and degree pluralities

one backpack, and only one backpack John carries weighs the same as one Mary carries.

(18) John carries two backpacks a and b; a weighs $10 \mathrm{kgs}$ and b 15kgs;

Mary carries two c and d; c weighs 10kgs and d 5kgs.

Judgment making in such a scenario seems to become not so easy. Schwarz (2007) reports that intuitively the German example (6) may be true or false in such a scenario. To the ears of mine and other speakers' I have consulted, the Mandarin example (7) is difficult to judge in this scenario and might hardly be true. Nevertheless, with extra contextual information added in, judgment making may become much easier: as shown in (19), with additional contextual information, (7) may be easily judged true against the scenario in (18).

(19) All the students randomly pick two backpacks to carry in the hiking trip. Before taking off, let's weigh the backpacks they choose and see whether there are any two students who get at least two backpacks that have the same weight. It then happens that ...

Yuēhàn hé Mălì bēi-le yíyàng zhòng-de bēibāo.

John and Mary carry-PERF equally heavy-MOD backpack

'John and Mary carried/carry equally heavy backpacks.'

A different choice of verb might make judgment making easier as well. In contrast to (7), (20a), where the verb is changed to tiāo 'pick', (20a) may be easily judged true in a scenario (e.g., (20b)) very similar to the one in (18).

(20) a. Yuēhàn hé Mălì tiāo-le yíyàng zhòng-de bēibāo.

John and Mary pick-PERF equally heavy-MOD backpack

'John and Mary picked equally heavy backpacks.'

b. John picks two backpacks weighing $10 \mathrm{kgs}$ and $15 \mathrm{kgs}$ respectively;

Mary picks two weighing $10 \mathrm{kgs}$ and $5 \mathrm{kgs}$ respectively.

All these observations suggest that intuitions around an adnominal RE may be vague about the contribution of each individual in comparison and may be sensitive to the context of utterance. This is reminiscent of the vagueness observed in plural predication, where the contribution of each individual is also vague and contextdependent (Schwarzschild 1996; a.o.).

\subsection{Roadmap}

An adequate analysis of REs should not only cover the data discussed in section 1.1 but also reflect the vagueness and contextual dependency illustrated in section 1.2; 
this paper aims to achieve this goal. Below I first review Schwarz's (2007) pioneer analysis and discuss some of its problems. In Section 3 I review the theory of plural predication the proposal is couched on and the idea of 'degree plurality' suggested by Dotlačil \& Nouwen (2016). My analysis of the semantics of the RE morpheme is laid out in Section 4. Amount REs are discussed in Section 5. Section 6 centers on the vagueness and context dependency observed in an adnominal reciprocal equative; the discussion reveals how delicately plurality in the domain of individuals interacts with that in the domain of degrees. Section 7 is the conclusion.

\section{Schwarz's (2007) analysis}

Building on the assumption that a gradable predicate such as heavy relates a degree $d$ and an individual $x$ in the way that x's weight at least reaches $d$ (see (21a)), Schwarz suggests that a reciprocal equative morpheme such as German gleich relates a gradable predicate $\mathrm{R}$ and a plural individual X (see (21b)) and asserts that all the relevant subparts of $X$ have the same degree with respect to $R$.

a. $\llbracket$ schwer $/$ heavy $\rrbracket=\lambda \mathrm{d}_{\mathrm{d}} \cdot \lambda \mathrm{x}_{\mathrm{e}} \cdot \mu_{\text {weight }}(\mathrm{x}) \geq \mathrm{d}$

(where $\mu_{\text {weight }}$ is a measure function that maps $\mathrm{x}$ to $\mathrm{x}$ 's weight )

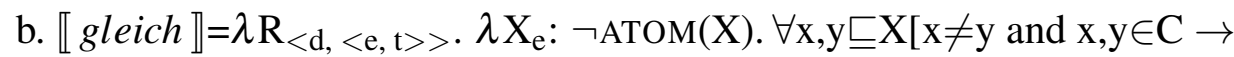

$$
\{\mathrm{d}: \mathrm{R}(\mathrm{d})(\mathrm{x})\}=\{\mathrm{d}: \mathrm{R}(\mathrm{d})(\mathrm{y})\}]
$$

In (21b), $C$ is the contextual restriction on plural predication and may be taken to be a cover á la Schwarzschild (1996). Along with these assumptions, the truth conditions (22) may be derived for (2): with the natural assumption that $\mathrm{C}$ contains the individuals Hans and Maria, these truth conditions then say that the weight of Hans is equivalent to that of Maria.

$$
\begin{aligned}
& \llbracket[\text { Hans and Maria }] \text { are }[\text { gleich heavy }] \rrbracket=1 \text { iff } \\
& \forall \mathrm{x}, \mathrm{y} \sqsubseteq(\mathrm{H} \sqcup \mathrm{M})\left[\mathrm{x} \neq \mathrm{y} \text { and } \mathrm{x}, \mathrm{y} \in \mathrm{C} \rightarrow\left\{\mathrm{d}: \mu_{\text {weight }}(\mathrm{x}) \geq \mathrm{d}\right\}=\left\{\mathrm{d}: \mathrm{d}: \mu_{\text {weight }}(\mathrm{y}) \geq \mathrm{d}\right\}\right]
\end{aligned}
$$

The reciprocal equative morpheme need not be interpreted in situ. When combined with a relational gradable adjective like angry (see (23)), gleich moves out of its base-generation position (see $(24 a-24 b)$ ) to resolve type mismatch. In the LF in (24b), $d$ is the degree variable left after the movement of gliech.

(23) Hans und Maria sind mir gleich böse.

Hans and Maria are me.DAT equally angry

'Hans and Maria are equally angry at me.'

a. $\llbracket$ angry/böse $\rrbracket=\lambda \mathrm{d}_{\mathrm{d}} \cdot \lambda \mathrm{x}_{\mathrm{e}} \cdot \lambda \mathrm{y}_{\mathrm{e}} \cdot \mu_{\text {anger-at-x }}(\mathrm{y}) \geq \mathrm{d}$

b. 【[ H\&M [ gleich [ 1 [ [ $d_{1}$ angry-at me $\left.\left.\left.]\right]\right]\right] \rrbracket=1$ iff $\forall \mathrm{x}, \mathrm{y} \sqsubseteq(\mathrm{H} \sqcup \mathrm{M})[\mathrm{x} \neq \mathrm{y}$ and $\mathrm{x}, \mathrm{y} \in \mathrm{C} \rightarrow$

$\{d$ : $x$ is d-angry at me $\}=\{d: y$ is d-angry at me $\}]$ 
Schwarz (2007) also points out that in an amount reciprocal equative like (8), gleich must move out of its base-generation position and gets interpreted outside its containing DP. ${ }^{2}$ Assuming that in (25b) C contains the group of the pets Hans has and that of the pets Maria has, the derived truth conditions amount to saying that the number of the pets Hans has is the same as that of those Maria has. In (25b), the pluralization operators * and ** are are used and understood in the way as in Link (1983), Sternefeld (1998), Beck $(2000,2001)$ and many others.

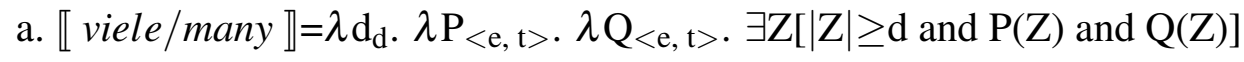

$$
\begin{aligned}
& \text { b. 【[ H\&M [gleich [ } \left.\left.\left.1\left[* * \text { have }\left[\exists\left[\left[d_{1} \text { many }\right] * \text { cat }\right]\right]\right]\right]\right]\right] \rrbracket=1 \text { iff } \\
& \forall \mathrm{x}, \mathrm{y} \sqsubseteq(\mathrm{H} \sqcup \mathrm{M})[\mathrm{x} \neq \mathrm{y} \text { and } \mathrm{x}, \mathrm{y} \in \mathrm{C} \rightarrow \\
& \{\mathrm{d}: \exists \mathrm{Z}[* \operatorname{pet}(\mathrm{Z}) \text { and }|\mathrm{Z}| \geq \mathrm{d} \text { and } * * \operatorname{have}(\mathrm{Z})(\mathrm{x})]\}= \\
& \{\mathrm{d}: \exists \mathrm{Z}[* \operatorname{pet}(\mathrm{Z}) \text { and }|\mathrm{Z}| \geq \mathrm{d} \text { and } * * \operatorname{have}(\mathrm{Z})(\mathrm{y})]\}]
\end{aligned}
$$

An adnominal reciprocal equative like (6), in this analysis, may be parsed in two different ways. In one, gleich is interpreted in situ (see (26a)); in the other, gleich moves out of its containing DP at LF (see (27a)). As Schwarz (2007) notes, these two LF's, in a context in which Hans and Maria each carry just one backpack (see (17)), lead to the same prediction: assuming that $\mathrm{C}$ in (26a) contains each of the backpack Hans and Maria carry respectively and on the other hand that in (27a) contains the individuals Hans and Maria, these two sets of truth conditions both predict that (6) is true iff the backpacks they carry weigh the same.

$$
\begin{aligned}
& \text { a. LF } 1 \text { of (6): [ H\&M [**carry }[\exists[\text { [ gleich heavy }] * \text { backpacks }]]]] \\
& \text { b. } \llbracket(26 \mathrm{a}) \rrbracket=1 \text { iff } \exists \mathrm{Z}[* \mathrm{bp}(\mathrm{Z}) \text { and } * * \text { carry }(\mathrm{Z})(\mathrm{H} \& \mathrm{M}) \text { and } \\
& \forall \mathrm{x}, \mathrm{y} \sqsubseteq \mathrm{Z}[\mathrm{x}, \mathrm{y} \in \mathrm{C} \text { and } \mathrm{x} \neq \mathrm{y} \rightarrow \\
& \left.\left.\left\{\mathrm{d}: \mu_{\text {weight }}(\mathrm{x}) \geq \mathrm{d}\right\}=\left\{\mathrm{d}: \mu_{\text {weight }}(\mathrm{y}) \geq \mathrm{d}\right\}\right]\right]
\end{aligned}
$$
a. LF 2 of (6):
[ H\&M [ gleich [ 1 [**carry [ $\exists\left[\left[d_{1}\right.\right.$ heavy $] *$ backpacks ]]]]]]
b. 【 (27a) $\rrbracket=1$ iff $\forall \mathrm{x}, \mathrm{y} \sqsubseteq(\mathrm{H} \sqcup \mathrm{M})[\mathrm{x}, \mathrm{y} \in \mathrm{C}$ and $\mathrm{x} \neq \mathrm{y} \rightarrow$
$\left\{\mathrm{d}: \exists \mathrm{Z}\left[* \mathrm{bp}(\mathrm{Z})\right.\right.$ and $* * \operatorname{carry}(\mathrm{Z})(\mathrm{x})$ and $\left.\left.\mu_{\text {weight }} \geq \mathrm{d}\right]\right\}=$
$\left\{\mathrm{d}: \exists \mathrm{Z}\left[* \mathrm{bp}(\mathrm{Z})\right.\right.$ and $* * \operatorname{carry}(\mathrm{Z})(\mathrm{y})$ and $\left.\left.\left.\mu_{\text {weight }} \geq \mathrm{d}\right]\right\}\right]$

Nevertheless, in a scenario like (18), where Hans and Maria each carry two backpacks, these two LF's lead to different predictions: while (26b) predicts that (6) is true against this scenario, (27b) predicts that it is false. Given that as Schwarz (2007) reports, (6), intuitively, can be true or false in this scenario, he concludes that both analyses are consistent with intuitions.

2 Having gliech interpreted in situ in an amount reciprocal equative, in Schwarz's analysis, leads to the truth conditions that further lead to the wrong prediction that Hans and Maria have equally many cats entails Hans and Maria have equally many pets. I refer the reader to Schwarz (2007) for detailed discussion. 
Promising as it might initially seem to be, Schwarz's (2007) analysis suffers from several problems some of which are already noted by himself. One of them has to do with universal REs' like (13-15). As Schwarz notes himself, it is unclear how such cases may be addressed in his analysis. Another challenge Schwarz's faces comes from examples like (28) (from German) and its Mandarin counterpart (29). In these examples, the number of the dogs John has and that of the cats he has are being compared.

(28) Hans hat gleich viele Hunde und Katzen.

Hans has equally many dogs and cats

'Hans has equally many dogs and cats.'

(29) Yuēhàn yăng-le yíyàng dūo-de gŏu gēn māo.

John keep-PERF equally many-MOD dog and cat

'John has equally many dogs and cats.'

As noted above, in an amount reciprocal equative, a reciprocal equative morpheme, in Schwarz's setting, must move out of the containing DP. Nevertheless, having the reciprocal equative morpheme interpreted DP-externally in these cases wrongly predicts that (28-29) are unacceptable for the reason why *John has equally many dogs is.

\section{Plural predication and Degree Plurality}

In this section, I review some assumptions the proposal relies on; these include i) a theory of plural predication that makes use of the pluralization operators * and ** that are constrained by covers and ii) Dotlačil \& Nouwen's (2016) idea of degree plurality.

\subsection{Plural Predication, Distributivity and Cumulativity}

Following Link (1983), Sternefeld (1998), Beck (2000, 2001) and many others, I assume that the pluralization operations $*$ and $* *$ are introduced through operators present at LF. * gives rise to the distributive reading of, e.g., John and Mary left, according to which John left and Mary, too, did; ** gives rise to the so called 'cumulative reading' of, e.g., John and Mary love Bill and Sue, according to which each of John and Mary loves one of Bill and Sue, and each of Bill and Sue is loved by one of John and Mary. Both operations are sensitive to covers $\mathrm{C}$ á la Schwarzschild (1996), a salient way in the context of utterance objects in the universe of discourse are divided into groups.

$$
\text { a. } \llbracket * \rrbracket(\mathrm{C})\left(\mathrm{P}_{<\mathrm{e}, \mathrm{t}>}\right)=\lambda \mathrm{X}_{\mathrm{e}} . \forall \mathrm{x} \sqsubseteq \mathrm{X}[\mathrm{x} \in \mathrm{C} \rightarrow[* \mathrm{P}](\mathrm{x})]
$$


Reciprocal Degree operators and degree pluralities

b. Distribution:

* is that function: $\mathrm{D}_{<\mathrm{e}, \mathrm{t}>} \rightarrow \mathrm{D}_{<\mathrm{e}, \mathrm{t}>}$ such that for any $\mathrm{f} \in \mathrm{D}_{<\mathrm{e}, \mathrm{t}>}$ and any $\mathrm{x}$ in $\mathrm{D}_{\mathrm{e}},\left[{ }^{*} \mathrm{f}(\mathrm{x})\right]=1$ iff $\mathrm{f}(\mathrm{x})=1$ or $\exists \mathrm{u} \exists \mathrm{v}\left[\mathrm{x}=\mathrm{u} \sqcup \mathrm{v}\right.$ and $[* \mathrm{f}](\mathrm{u})$ and $\left.\left[{ }^{*} \mathrm{f}\right](\mathrm{v})\right]$

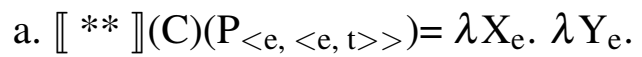

$$
\begin{aligned}
& \forall \mathrm{y} \sqsubseteq \mathrm{Y}[\mathrm{y} \in \mathrm{C} \rightarrow \exists \mathrm{X} \sqsubseteq \mathrm{x}[\mathrm{x} \in \mathrm{C} \text { and }[* * \mathrm{P}](\mathrm{x})(\mathrm{y})]] \text { and } \\
& \forall \mathrm{x} \sqsubseteq \mathrm{X}[\mathrm{x} \in \mathrm{C} \rightarrow \exists \mathrm{y} \sqsubseteq \mathrm{Y}[\mathrm{y} \in \mathrm{C} \text { and }[* * \mathrm{P}](\mathrm{x})(\mathrm{y})]]
\end{aligned}
$$

\section{b. Cumulation:}

$* *$ is that function: $\mathrm{D}_{<\mathrm{e},<\mathrm{e}, \mathrm{t}>>} \rightarrow \mathrm{D}_{<\mathrm{e},<\mathrm{e}, \mathrm{t}>>}$ such that for any

$\mathrm{R} \in \mathrm{D}_{<\mathrm{e},<\mathrm{e}, \mathrm{t}>>}$ and any $\mathrm{x}, \mathrm{y}$ such that $\mathrm{x} \in \mathrm{D}_{\mathrm{e}}$ and $\mathrm{y} \in \mathrm{D}_{\mathrm{e}},[* * \mathrm{R}](\mathrm{x})(\mathrm{y})=1$ iff:

$\mathrm{R}(\mathrm{x})(\mathrm{y})$ or

$\exists \mathrm{x}_{1} \exists \mathrm{x}_{2} \exists \mathrm{y}_{1} \exists \mathrm{y}_{2}\left[\mathrm{x}=\mathrm{x}_{1} \sqcup \mathrm{x}_{2} \wedge \mathrm{y} \mathrm{y}_{1} \sqcup \mathrm{y}_{2} \wedge[* * \mathrm{R}]\left(\mathrm{x}_{1}\right)\left(\mathrm{y}_{1}\right) \wedge[* * \mathrm{R}]\left(\mathrm{x}_{2}\right)\left(\mathrm{y}_{2}\right)\right]$

\subsection{Degree plurality}

Much research (e.g., Fitzgibbons, Sharvit \& Gajewski 2008; Beck 2010, 2013, 2014; Dotlačil \& Nouwen 2016) suggests that the ontology and semantic mechanism designated for plurality of individuals should be extended to degrees. Among them, Dotlačil \& Nouwen (2016) explicitly suggest that one may form a sum of degrees via the same summation operation according to which a sum of individuals is formed: for any two degrees $d$ and $\mathrm{d}^{\prime}, \mathrm{d} \sqcup \mathrm{d}^{\prime}$ is the sum of $\mathrm{d}$ and $\mathrm{d}^{\prime}$. As Dotlačil \& Nouwen (2016) notes, it is not surprising that the semantic mechanisms governing plurality formation and plural predication may be exteded to degrees, given that degrees and entities behave very much alike. For instance, (32a) carries a cumulative interpretation (e.g., John is 20 years old, Peter is 22, and Mary 26) in the way that (32b) possibly could (e.g., John likes Bill, Peter likes Chris and Mary likes Sue). This suggests that the same cumulation relation may be involved in both (32a) and (32b).

a. John, Peter and Mary are 20, 22 and 26 years old.

b. John, Peter and Mary like Bill, Chris and Sue.

Building on this idea, Dotlačil \& Nouwen further suggest that a gradable adjective such as tall relates a sum $\mathrm{d}$ of degrees and an individual $\mathrm{x}$ in the way that the height of $\mathrm{x}$ (i.e., $\mu_{\text {height }}(\mathrm{x})$ ) is part of $\mathrm{d}$ (see (33a)). An operator MIN is postulated to pick out the unique member $\mathrm{d}^{\prime}$ from a set $\mathrm{D}$ of sums of degrees such that $\mathrm{d}^{\prime}$ does not contain any other members in D as its subpart. Take John's height for instance; applying MIN to the set of sums d of degrees that contain John's height (i.e., $\left.\mu_{\text {height }}(\mathrm{J}) \sqsubseteq \mathrm{d}\right)$ gives John's height (i.e., $\mu_{\text {height }}(\mathrm{J})$ ) (see (34)).

a. $\llbracket$ tall $\rrbracket=\lambda \mathrm{d}_{\mathrm{d}} \cdot \lambda \mathrm{x}_{\mathrm{e}} \cdot \mu_{\text {height }}(\mathrm{x}) \sqsubseteq \mathrm{d}$

b. For any $\mathrm{D}^{\prime} \in \mathrm{D}_{<\mathrm{d}, \mathrm{t}>}, \operatorname{MIN}\left(\mathrm{D}^{\prime}\right)=\imath \mathrm{d}\left[\mathrm{D}^{\prime}(\mathrm{d})\right.$ and $\neg \exists \mathrm{d}^{\prime}\left[\mathrm{D}^{\prime}\left(\mathrm{d}^{\prime}\right)\right.$ and $\left.\left.\mathrm{d}^{\prime} \sqsubset \mathrm{d}\right]\right]$; otherwise, undefined. 


$$
\begin{aligned}
& \text { If } \mu_{\text {height }}(\mathrm{J})=180 \mathrm{~cm},\{\mathrm{~d}: \llbracket \text { tall } \rrbracket(\mathrm{d})(\mathrm{J})\}=\left\{\mathrm{d}: \mu_{\text {height }}(\mathrm{J}) \sqsubseteq \mathrm{d}\right\}=\{\mathrm{d}: 180 \mathrm{~cm} \sqsubseteq \mathrm{d}\} ; \\
& \operatorname{MIN}\left(\lambda \mathrm{d} . \mu_{\text {height }}(\mathrm{J}) \sqsubseteq \mathrm{d}\right)=\mu_{\text {height }}(\mathrm{J})
\end{aligned}
$$

Dotlačil \& Nouwen's (2016) main goal is to account for comparatives with a universal quantifier inside the than-clause. ${ }^{3}$ Intuitively, John is taller than every girl is is true iff John is taller than the tallest girl. Along with their idea, this intuition may be captured in the following way. Suppose that there are three girls, namely $\mathrm{a}, \mathrm{b}$ and $\mathrm{c}$, in the context of utterance; the than-clause then denotes the set of sums $d$ of degrees such that $d$ contains every girl's height as its subparts (see (35a); i.e., $\left.\left(\mu_{\text {height }}(\mathrm{a}) \sqcup \mu_{\text {height }}(\mathrm{b}) \sqcup \mu_{\text {height }}(\mathrm{c})\right) \sqsubseteq \mathrm{d}\right)$; MIN then picks out the unique sum from this set that contains all and only every girl's height (i.e., $\mu_{\text {height }}(\mathrm{a}) \sqcup \mu_{\text {height }}(\mathrm{b}) \sqcup \mu_{\text {height }}(\mathrm{c})$ ). With the application of the cumulation operation **, the truth conditions (35b) are derived, which amounts to saying that $\mu_{\text {height }}(\mathrm{J})$ is greater than all of $\mu_{\text {height }}(\mathrm{a})$, $\mu_{\text {height }}(\mathrm{b})$ and $\mu_{\text {height }}(\mathrm{c})$. This then correctly predicts that John is taller than every girl is is true only if John is taller than the tallest girl.

$$
\begin{aligned}
& \text { a. 【 than every girl is all } \rrbracket=\lambda \mathrm{d}_{\mathrm{d}} . \forall \mathrm{x}\left[\mathrm{x} \text { is a girl } \rightarrow \mu_{\text {height }}(\mathrm{x}) \sqsubseteq \mathrm{d}\right] \\
& \text { b. } \mu_{\text {height }}(\mathrm{J})\left[{ }^{* *}>\right] \operatorname{MIN}\left(\lambda \mathrm{d} \text {. } \forall \mathrm{x}\left[\mathrm{x} \text { is a } \operatorname{girl} \rightarrow \mu_{\text {height }}(\mathrm{x}) \sqsubseteq \mathrm{d}\right]\right)
\end{aligned}
$$

\section{Predicative REs}

Along with the assumptions laid out above, I suggest that a reciprocal equative morpheme such as yíyàng/gleich/equally has the denotation in (36).

$$
\llbracket \text { yíyàng/gleich/equally } \rrbracket=\lambda \mathrm{D}^{\prime}<\mathrm{d}, \mathrm{t}>\cdot \forall \mathrm{d}^{\prime}, \mathrm{d}^{\prime \prime}\left[\mathrm{d}^{\prime}, \mathrm{d}^{\prime \prime} \sqsubseteq \mathrm{MIN}\left(\mathrm{D}^{\prime}\right) \rightarrow \mathrm{d}^{\prime}=\mathrm{d}^{\prime \prime}\right]
$$

A reciprocal equative morpheme operates on a set of sums of degrees and asserts that the unique member picked out by MIN has subparts mutually equivalent. At LF, it moves out of its base-generation position and leaves a degree variable bound a $\lambda$-abstractor (c.f., Heim \& Kratzer 1998).

$$
\begin{aligned}
& {\left[\mathrm{AP} \text { yíyàng/gleich/equally }\left[\mathrm{A}^{\prime} \text { heavy }\right]\right] \Rightarrow} \\
& {\left[\text { yíyàng/gleich/equally }\left[7\left[\ldots\left[\mathrm{AP} d_{7}\left[\mathrm{~A}^{\prime} \text { heavy }\right]\right]\right]\right]\right.}
\end{aligned}
$$

The predicative reciprocal equative such as (1-3) then may be analyzed as in (38): with the natural assumption that the cover $\mathrm{C}$ contains each of the individuals John and Mary, MIN picks out the unique sum d of degrees that contains all and only the weight of John and that of Mary; the derived truth conditions then say that all the subparts of $d$ are mutually equivalent, which amounts to saying that John's weight is the same as Mary's.

3 For detailed discussion on quantifiers in the than-clause, see Beck (2010, 2014), Alrenga \& Kennedy (2014), Dotlačil \& Nouwen (2016) and the references cited therein. 
Reciprocal Degree operators and degree pluralities
a. [ yíyàng/gleich/equally [ 7 [ J\&M [ [*C] [AP $d_{7}$ heavy]]]]
b. $\llbracket$ heavy $\rrbracket=\lambda \mathrm{d}_{\mathrm{d}} \cdot \lambda \mathrm{x}_{\mathrm{e}} \cdot \mu_{\text {weight }}(\mathrm{x}) \sqsubseteq \mathrm{d}$
c. Let $\mathrm{C} \supseteq\{\mathrm{J}, \mathrm{M}\}$,
【ýyàng/gleich/equally $\rrbracket\left(\lambda \mathrm{d}_{\mathrm{d}} . \forall \mathrm{x} \sqsubseteq(\mathrm{J} \sqcup \mathrm{M})\left[\mathrm{x} \in \mathrm{C} \rightarrow \mu_{\text {weight }}(\mathrm{x}) \sqsubseteq \mathrm{d}\right]\right)=1$ iff: $\forall \mathrm{d}^{\prime}, \mathrm{d}^{\prime \prime}\left[\mathrm{d}^{\prime}, \mathrm{d}^{\prime \prime} \sqsubseteq \mathrm{MIN}\left(\lambda \mathrm{d}_{\mathrm{d}} . \forall \mathrm{x} \sqsubseteq(\mathrm{J} \sqcup \mathrm{M})\left[\mathrm{x} \in \mathrm{C} \rightarrow \mu_{\text {weight }}(\mathrm{x}) \sqsubseteq \mathrm{d}\right]\right) \rightarrow \mathrm{d}^{\prime}=\mathrm{d}^{\prime \prime}\right]$
'The unique sum of degrees that contains only $\mu_{\text {weight }}(\mathrm{J})$ and $\mu_{\text {weight }}(\mathrm{M})$ has subparts that are mutually equivalent.'

With the idea laid out above, a universal reciprocal equative like (39) may be accounted for in a very similar way a comparative with a universal quantifier in the than-clause is accounted for. In (39), the reciprocal degree morpheme takes as its argument the set of sums of degrees that contain the thickness of every steak (see (40b)); the operator MIN then picks out the unique element in this set that does not contain any other members in this set as its subpart.

\section{mĕi-yī-kuài niúpái dōu yíyàng hòu.}

every-one-CL steak all equally thick

'Every steak is equally thick.'

$$
\begin{aligned}
& \text { a. [ yíyàng }\left[7 \text { [ every steak } \left[d_{7}\right.\right. \text { thick ] ] ] ] } \\
& \text { b. 【[ } \left.\left.7 \text { [ every steak }\left[d_{7} \text { thick }\right]\right]\right] \rrbracket=\lambda \mathrm{d}_{\mathrm{d}} \cdot \forall \mathrm{x}\left[\mathrm{x} \text { is a steak } \rightarrow \mu_{\text {thickness }}(\mathrm{x}) \sqsubseteq \mathrm{d}\right] \\
& \llbracket(39 / 40 \mathrm{a}) \rrbracket=\llbracket \text { ý́yàng } \rrbracket\left(\lambda \mathrm{d}_{\mathrm{d}} . \forall \mathrm{x}\left[\mathrm{x} \text { is a steak } \rightarrow \mu_{\text {thickness }}(\mathrm{x}) \sqsubseteq \mathrm{d}\right]\right)=1 \\
& \quad \text { iff } \forall \mathrm{d}^{\prime}, \mathrm{d}^{\prime \prime}\left[\mathrm{d}^{\prime}, \mathrm{d}^{\prime \prime} \sqsubseteq \mathrm{MIN}\left(\lambda \mathrm{d}_{\mathrm{d}} \cdot \forall \mathrm{x}\left[\mathrm{x} \text { is a steak } \rightarrow \mu_{\text {thickness }}(\mathrm{x}) \sqsubseteq \mathrm{d}\right]\right) \rightarrow \mathrm{d}^{\prime}=\mathrm{d}^{\prime \prime}\right]
\end{aligned}
$$

The derived truth conditions say that all the subparts of the unique sum of degrees picked out by MIN are mutually equivalent. Suppose that the steaks in comparison are $\mathrm{a}, \mathrm{b}$, and $\mathrm{c}$; the set of sums of degrees yíyàng operates on contains all and only those that have as their subpart $\mu_{\text {thickness }}(\mathrm{a}) \sqcup \mu_{\text {thickness }}(\mathrm{b}) \sqcup \mu_{\text {thickness }}$ (c); MIN then picks out the sum $\mu_{\text {thickness }}(\mathrm{a}) \sqcup \mu_{\text {thickness }}(\mathrm{b}) \sqcup \mu_{\text {thickness }}(\mathrm{c})$. By saying that all the subparts of $\mu_{\text {thickness }}(\mathrm{a}) \sqcup \mu_{\text {thickness }}$ (b) $\sqcup \mu_{\text {thickness }}$ (c) are mutually equivalent, the derived truth conditions amount to saying that $\mu_{\text {thickness }}(\mathrm{a})=\mu_{\text {thickness }}(\mathrm{b})=\mu_{\text {thickness }}(\mathrm{c})$.

\section{Amount REs}

A piece required to account for an amount reciprocal equative like (10)/(11) is the syntax and semantics of Q-adjectives. It has been suggested recently that although the meaning of Q-adjectives involves gradability, measurement of quantity is not introduced by these elements; instead, it is introduced via a functional head that co-occurs with the Q-adjectives (Rett 2008; Solt 2015; and others). Below I work with Solt's (2015) analysis, according to which Q-adjectives have quite a trivial semantics and do not encode a measure function in their lexical meaning (see (41a)). Measurement of quantity, instead, is introduced by the functional head Meas, whose 
lexical meaning, along with Dotlačil \& Nouwen's (2016) idea of degree plurality, is given in (41b). Following Solt (2015), I further assume the compositional rule Degree Argument Introduction to resolve the type-mismatch between Meas and the NP it combines with.

a. 【many/much/viele/dīo $\rrbracket=\lambda \mathrm{d}_{\mathrm{d}} \cdot \lambda \mathrm{I}_{<\mathrm{d}, \mathrm{t}>} \cdot \mathrm{I}(\mathrm{d})$

b. $\llbracket$ Meas $\rrbracket=\lambda \mathrm{x}_{\mathrm{e}} \cdot \lambda \mathrm{d}_{\mathrm{d}} \cdot \mu_{\text {quantity }}(\mathrm{x}) \sqsubseteq \mathrm{d}$

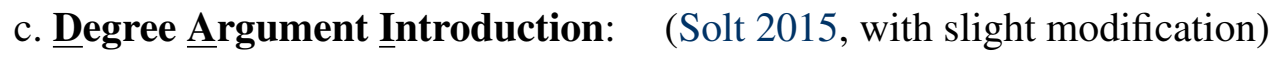
For any branching node $\alpha$, whose daughters are $\beta$ and $\gamma$, if $\llbracket \beta \rrbracket \in \mathrm{D}_{<\mathrm{e}, \mathrm{t}>}$

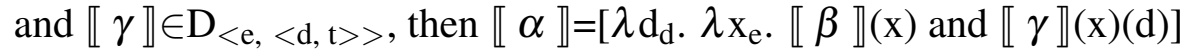

Along with these assumptions and the LF in (42), the truth conditions of (10)/(11) are derived as in (43b).

(42) [ yíyàng/gleich [(2) $7\left[\right.$ [ [QP $d_{7}$ many ] [(1) $5\left[\right.$ [ConjP [DP 1 [MeasP $d_{5}$ [Meas' $^{\prime}$

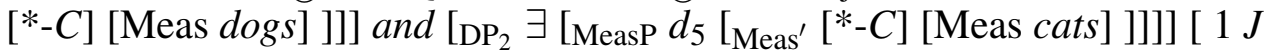

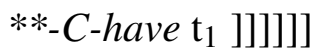

a. $\llbracket$ and $\rrbracket=\lambda \mathrm{P}_{<\tau, \mathrm{t}>} \cdot \lambda \mathrm{Q}_{<\tau, \mathrm{t}>} \cdot \lambda \mathrm{x}_{\tau} . \mathrm{P}(\mathrm{x})$ and $\mathrm{Q}(\mathrm{x}) \quad(\tau$ is a semantic type $)$

(Champollion 2016)

$$
\begin{aligned}
& \llbracket \mathrm{DP}_{1 / 2} \rrbracket=\lambda \mathrm{P}_{<\mathrm{e}, \mathrm{t}>} \cdot \exists \mathrm{X}\left[\forall \mathrm{x} \sqsubseteq \mathrm{X}\left[\mathrm{x} \in \mathrm{C} \rightarrow * \operatorname{dog} / * \operatorname{cat}(\mathrm{x}) \text { and } \mu_{\text {quantity }}(\mathrm{x}) \sqsubseteq \mathrm{d}\right]\right. \\
& \text { and } \mathrm{P}(\mathrm{X})]
\end{aligned}
$$

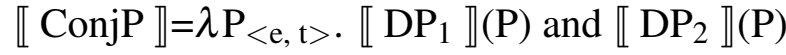

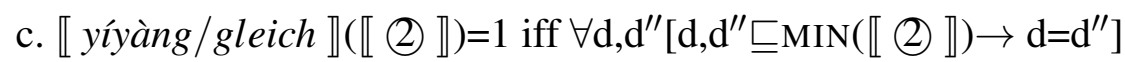

'(with $\mathrm{C} \supseteq\{\mathrm{J}$, the-cats-he-has, the-dogs-he-has $\}$ ) the unique sum $\mathrm{d}$ that contains only the number of the dogs John has and the number of the cats John has has mutually equivalent subparts. '

With the natural assumption that $\mathrm{C}$ contains $\mathrm{J}$, the sum of the dogs $\mathrm{J}$ has, and the sum of the cats he has, MIN operates on the set of sums of degrees that contain $\mu_{\text {quantity }}$ (the-dogs-J-has) $\sqcup \mu_{\text {quantity }}$ (the-cats-J-has) and picks out this sum of degrees. The truth conditions derived then assert that $\mu_{\text {quantity }}$ (the-cats-J-has) $\sqcup \mu_{\text {quantity }}$ (thecats-Mary-has) has mutually equivalent subparts, which amounts to saying that the number of the cats John has is exactly the same as the number of the dogs he has. 
Reciprocal Degree operators and degree pluralities

\section{Adnominal REs and vagueness}

As noted above, intuitions around an adnominal reciprocal equative like (6)/(7) may be vague; it can be true or false in a scenario like (2), where each of John and Mary carries more than one backpack, and only one of those John carries weighs the same as one of those Mary carries. Schwarz (2007) captures this vague intuition by assigning multiple LFs' to examples of this kind. In the alternative analysis I have suggested above, a reciprocal equative morpheme moves obligatorily at LF; therefore, the vagueness observed can no longer be accounted for by assigning (6)/(7) multiple LF's. Instead, I suggest that this should be captured via manipulation of covers, the contextual restriction on plural predication.

Along with the proposal and the LF (44a), the truth conditions (44b) are derived for $(6) /(7)$.

$$
\begin{aligned}
& \text { a. [ yíyàng/gleich/equally [(1) } 7 \text { [ [DP } \exists\left[\left[[ * C ] \left[d_{7} \text { heavy ]] backpacks ]] } 1\right.\right.\right. \text { [ } \\
& \forall \mathrm{y} \sqsubseteq(\mathrm{J} \sqcup \mathrm{M})[\mathrm{y} \in \mathrm{C} \rightarrow \exists \mathrm{x} \sqsubseteq \mathrm{X}[\mathrm{x} \in \mathrm{C} \text { and } * * \operatorname{carry}(\mathrm{x})(\mathrm{y})] \text { and } \\
& \forall \mathrm{x} \sqsubseteq \mathrm{X}[\mathrm{x} \in \mathrm{C} \rightarrow \exists \mathrm{y} \sqsubseteq(\mathrm{J} \sqcup \mathrm{M})[\mathrm{y} \in \mathrm{C} \text { and } * * \operatorname{carry}(\mathrm{x})(\mathrm{y})]]
\end{aligned}
$$

In the scenario in which John and Mary each carry only one backpack, these truth conditions, with the natural assumption that $\mathrm{C}$ contains John, Mary, the backpack John carries and that Mary carries, correctly predict that (6)/(7) is true iff the weight of John's backpack is the same as that of Mary's.

The situation gets complicated in a scenario like (18), where John and Mary each carry more than one backpack. With this scenario in mind, let's first consider the possibility according to which C contains John, Mary and each individual backpack carried by either of them (i.e., $\{\mathrm{J}, \mathrm{M}, \mathrm{a}, \mathrm{b}, \mathrm{c}, \mathrm{d}\} \subseteq \mathrm{C}$ ). With this possibility, the reciprocal equative morpheme operates on the set of sums of degrees in (45); MIN then serves to pick out the unique sum from this set that does not contain any other members as its subpart.

(45) \{d: d conatins as its subparts at least one of $15 \mathrm{~kg} \sqcup 5 \mathbf{k g}, 15 \mathrm{~kg} \sqcup 10 \mathrm{~kg}, 10 \mathrm{~kg} \sqcup 5 \mathrm{~kg}$, and $10 \mathrm{~kg}$ \}

Applying MIN to this set however leads to undefinedness: in this set, the sum $10 \mathrm{~kg}$ does not contain any other members as its subparts, and neither does the 
sum $15 \mathrm{~kg} \sqcup 5 \mathrm{~kg}$; MIN hence fails to pick out the unique member from this set. Consequently, (6)/(7) cannot be true with this value for $\mathrm{C}$.

It seems that the only possible value for $\mathrm{C}$ that may render $(6) /(7)$ true in (18) is one according to which it is a so-called 'ill-fitting cover' for the backpacks in this scenario (Brisson 1998, 2003). Being such a cover, C may contain the individual backpacks a and c but group $b$ and $d$ in a 'junkpile'. For instance, the backpacks $b$ and $\mathrm{d}$ are grouped together with $\mathrm{e}$, where e is some random object in the universe of discourse (i.e., $\{\mathrm{J}, \mathrm{M}, \mathrm{a}, \mathrm{c},(\mathrm{b} \sqcup \mathrm{d}) \sqcup \mathrm{e}\} \subseteq \mathrm{C}$ ). In this possibility, $\mathrm{b}$ and $\mathrm{d}$ escape quantification introduced via plural predication; the truth conditions derived in (44b) then may be satisfied in the scenario in (18) in the following way: the operator MIN picks out $10 \mathrm{kgs}, \mu_{\text {weight }}(\mathrm{b}) \sqcup \mu_{\text {weight }}(\mathrm{c})$, which has subparts mutually equivalent.

The idea of using an 'ill-fitting cover' in plural predication has been suggested to account for the tolerance of exceptions of a statement with definite plurals, such as the students built a raft. As already observed in various research, this sentence can be true even if there is one student who did not participate in any raft building. Brisson (1998, 2003) suggests that this intuition may be captured if the cover $\mathrm{C}$ groups the exceptions with some random objects in the universe of discourse so that they could escape from quantification introduced in plural predication. Along these lines, we may approach the vague intuition Schwarz (2007) reports in the following way. In an out-of-the-blue context, the default value for $\mathrm{C}$, according which it contains each individual backpack, leads to undefinedness; this explains why speakers might not consider (6)/(7) true in such a scenario. On the other hand, once an ill-fitting cover, such as the one discussed above, becomes a salient option available in the context of utterance, (6)/(7) then may be easily judged true in the same scenario. Compared to the possibility of $\mathrm{C}$ containing each individual backpack, that of $\mathrm{C}$ being an ill-fitting cover that groups the backpacks b and $d$ in (18) in a 'junkpile' is far from salient in an out-of-the-blue context. Such a context dependency explains why enrichment of the contextual information and a different choice of verb may render (7)/(6) get judged true against (18) more easily. As already shown in (19), if more contextual information is added. (7)/(6) would be judged true more easily in the scenario (18). The change of the verb from carry to pick, as shown in (20a), may have the very same effect. All these are expected if the source of the vagueness observed in (6)/(7) is the context-sensitivity of C; after all, the saliency of a cover is sensitive to the contextual information as well as the nature of the property distributed (Schwarzschild 1996). In these examples, the additional contextual information or the change of verb 'highlights' the backpacks that weigh the same and consequently, in Brisson's (1998) term, render those that do not weigh the same salient enough to be ignored. An ill-fitting cover that may render (6)/(7) true is then easier to be drawn by the hearer in face of a scenario like (18).

Intuitions around statements with plurals generally are vague about the contri- 
Reciprocal Degree operators and degree pluralities

bution of each individual in question and are sensitive to the context of utterance when large groups are involved. The discussion above shows that such vagueness and context sensitivity are observed in an adnominal RE as well. Along with the cover-based theory of plural predication the proposal is couched on, this may be seen as the result from the context sensitivity of covers.

\section{Conclusion}

It has been suggested repeatedly that plurality on degrees may have played a role in the semantic derivation of a degree construction, especially that of a comparative sentence with a quantifier in the than-clause (e.g., Heim 2006; Beck 2010, 2014; Dotlačil \& Nouwen 2016). Building on the insight of these work, I have attempted to extend the idea of degree plurality to reciprocal equatives, a degree construction that conveys reciprocity and equivalence. Taking Schwarz's (2007) pioneer study as the starting point, I offer an account for this degree construction that covers a wider range of data. The discussion not only provides new support for the need of building in plurality in degree semantics but also reveals the intricate interaction between plurality in the domain of degrees and that in the domain of individuals.

\section{References}

Alrenga, Peter \& Christopher Kennedy. 2014. No more shall we part: Quantifiers in English comparatives. Natural Language Semantics 22(1), 1-53. doi:10.1007/s11050-013-9099-4. http://dx.doi.org/10.1007/s11050-013-9099-4.

Beck, Sigrid. 2000. The semantics of different: Comparison operator and relational adjective. Linguistics and Philosophy 23(2), 101-139. doi:10.1023/A:1005566722022. http://dx.doi.org/10.1023/A:1005566722022.

Beck, Sigrid. 2001. Reciprocals are definites. Natural Language Semantics 9(1), 69-138. doi:10.1023/A:1012203407127. http://dx.doi.org/10.1023/A\% 3A1012203407127.

Beck, Sigrid. 2010. Quantifiers in than-clauses. Semantics and Pragmatics 3(1), 1-72. doi:10.3765/sp.3.1.

Beck, Sigrid. 2013. Lucinda driving too fast again-the scalar properties of ambiguous Than-clauses. Journal of Semantics 30(1), 1-63. doi:10.1093/jos/ffr011. http: //jos.oxfordjournals.org/content/30/1/1.abstract.

Beck, Sigrid. 2014. Plural predication and quantifier than-clauses. In Crnič. Luka \& Uli Sauerland (eds.), The Art and Craft of Semantics: A Festschrift for Irene Heim MITWPL 70, 91-115. Cambridge, MA: MIT Press.

Brisson, Christine. 2003. Plurals, all, and the nonuniformity of collective predication. 
Linguistics and Philosophy 26(2), 129-184. doi:10.1023/A:1022771705575. http://dx.doi.org/10.1023/A:1022771705575.

Brisson, Christine M. 1998. Distributivity, maximality, and floating quantifiers. New Brunswick, New Jersey: Rutgers PhD dissertation.

Champollion, Lucas. 2016. Ten men and women got married today: Noun coordination and the intersective theory of conjunction. Journal of Semantics 33(3), 561-622. doi:10.1093/jos/ffv008. http://jos.oxfordjournals.org/content/33/3/ 561.abstract.

Dotlačil, Jakub \& Rick Nouwen. 2016. The comparative and degree pluralities. Natural Language Semantics 24(1), 45-78. doi:10.1007/s11050-015-9119-7. http://dx.doi.org/10.1007/s11050-015-9119-7.

Fitzgibbons, Natalia, Yael Sharvit \& Jon Gajewski. 2008. Plural superlatives and distributivity. In Semantics and Linguistic Theory (SALT) 18, 302-318. doi:10.3765/salt.v18i0.2501. http://journals.linguisticsociety.org/proceedings/ index.php/SALT/article/view/2501.

Heim, Irene. 2006. Remarks on comparative clauses as generalized quantifiers. http://semanticsarchive.net/Archive/mJiMDBIN/comparatives\%20as\%20GQs.

Heim, Irene \& Angelika Kratzer. 1998. Semantics in Generative Grammar. Malden, MA: Blackwell.

Link, Godehard. 1983. The logical analysis of plurals and mass terms: A latticetheoretical approach. In Rainer Bauerle, Christoph Schwarze \& Arnim von Stechow (eds.), Meaning, Use and Interpretation of Language, 127-144. Berlin: de Gruyter.

Rett, Jessica. 2008. Degree modification in natural language. New Brunswick, New Jersey: Rutgers PhD dissertation.

Schwarz, Bernhard. 2007. Reciprocal equatives. In Estela Puig-Waldmüller (ed.), Proceedings of Sinn und Bedeutung 11., 568-582. Barcelona: Universitat Pompeu Fabra. http://www.upf.edu/dtf/sub11.

Schwarzschild, Roger. 1996. Pluralities. Dordrecht, the Netherlands: Kluwer Academic Publishers.

Solt, Stephanie. 2015. Q-adjectives and the semantics of quantity. Journal of Semantics 32(2), 221-273. doi:10.1093/jos/fft018. http://jos.oxfordjournals.org/ content/32/2/221.abstract.

Sternefeld, Wolfgang. 1998. Reciprocity and cumulative predication. Natural Language Semantics 6(3), 303-337. 
Reciprocal Degree operators and degree pluralities

I-Ta Chris Hsieh

Graduate Institute of Linguistics

National Tsing Hua University, Taiwan

101 Guangfu Road, Section 2, Hsinchu City, Taiwan 30013

ita.hsieh@mx.nthu.edu.tw 